\title{
VIEWPOINT
}

\section{Immigrant Integration and COVID-19}

\author{
Uzi Rebhun $^{1}$
}

\begin{abstract}
Covid-19 has thrust millions of people who have recently crossed international borders into unprecedented social and economic havoc. The patterns of immigration and settlement in a new country, on the one hand, and the nature of the virus, on the other hand, have placed immigrants at high risk of infection, possibly generating or accelerating antiimmigration sentiments among the local population. In this viewpoint, I discuss five complementary aspects of the migration-pandemic nexus: immigrants' legal status, language proficiency, ethnic segregation, religiosity, and economic wellbeing. My concluding remarks carry several implications for policy.
\end{abstract}

Keywords: Immigration; integration; COVID-19.

\section{Introduction}

The COVID-19 pandemic is the first grand worldwide challenge of the twenty-first century. The virus has rapidly spread from China to almost every country through people who traveled by air, sea, or rail, be it for business or for leisure (Keni et al., 2020). The global village, a metaphor that expresses the economic and cultural interconnectivity of different areas around the globe (McLuhan and Powers, 1992), now includes a health aspect that is allowing the lethal virus to affect billions of lives. Still, certain socio-demographic groups are more vulnerable to contagion than are others (Jin et al., 2021). The most salient, perhaps, are the elderly. Others are those with background conditions such as hypertension or diabetes. What both have in common is a weakened immune system. The coronavirus is also more threatening to men than to women. Several explanations have been offered for this, including different levels of immune protection of the lungs, the effect of sexual hormones, and a higher propensity to smoking - it, too, a risk factor for morbidity — among men. Further, the experience in the first few weeks of the pandemic has seen exceptionally high rates of illness among religio-ethnic communities in which small apartments, densely populated neighbourhoods, and mandatory public worship are prevalent (Szea et al., 2020).

Immigrants are another vulnerable population. Several characteristics that place them at a disadvantage in everyday life may be amplified under the conditions of the current pandemic, setting them at high risk of contagion. Indeed, immigrants are differently exposed to the virus. Their susceptibility is probably determined by contextual determinants of the receiving country, meso-variables of ethnic belonging, and individual socio-demographic and immigration characteristics. Basing myself on earlier theoretical and empirical literature on

\footnotetext{
${ }^{1}$ Uzi Rebhun, Professor and Head, Division of Jewish Demography and Statistics, The A. Harman Institute of Contemporary Jewry, The Hebrew University of Jerusalem, Jerusalem 91905, Israel. E-mail: uzi.rebhun@mail.huji.ac.il.
} 
immigration adaptation, I develop five features that I consider significant for immigrants amid the havoc of the coronavirus pandemic: legal status, language proficiency, ethnic segregation, religiosity, and economic wellbeing. I regard them as intervening settlement challenges between immigration, on the one hand, and health outcomes, on the other hand. The conclusion that I present at the end of this commentary carries several implications for policy.

\section{The Context}

This viewpoint joins the rich corpus of literature that references the nexus of immigration and health. This topic has been explored from different complementary angles including specific diseases (tuberculosis, hypertension), overweight, smoking, mental problems, sexual behaviour, healthcare access and use, e.g., cancer screening, and health inequality by origin, age, and gender. These studies invoke either subjective self-reportage on general health status or epidemiological objective tests. Among other sources, they utilize data from the New Immigrant Survey, the National Health Interview Survey, and SHARE. Findings on immigration and health have been published in various journals, chiefly including, over the last decade, Social Science and Medicine, Journal of Immigrant and Minority Health, and International Migration Review, as well as monographs and edited volumes. The concerns I express below may provide directions and stimulate empirical research in the field.

\section{The Immigration-COVID-19 Nexus}

\section{Legal Status}

Immigrants are roughly distinguished between legal and illegal/irregular. The latter include people who entered or were smuggled into the destination country in violation of its immigration laws and visitors who overstay their visas or residence permits, such as migrant workers and students (Blinder and Allen, 2016; Massey and Bartley, 2005; Van der Leun and Ilies, 2012). Although their exact number is unknown, it is estimated in the millions, with large concentrations in the United States, the European Union and the European Free Trade Association (especially Germany and the United Kingdom), Russia, and, in smaller numbers, Australia and Canada (Allard, 2019; Connor, Passel and Krogstad, 2019; Connor and Passel, 2019; Sciortino, 2012). Be their numbers as they may, that the share of illegal migrants in the overall immigrant population is growing is widely agreed (Massey and Capoferro, 2007). Illegal migrants are often invisible. They lead lives of fear, hiding, and perpetual concern about discovery and deportation (De Genova, 2002; Garcia, 2019; Van der Leun and Ilies, 2012). Under such circumstances, they strive to remain undocumented in all contexts. Since this implies that they lack health insurance, it stands to reason that they will avoid any test of being a carrier of the coronavirus. This not only worsens their own health but may cause them unintentionally to infect others. Likewise, in many countries with high rates of morbidity of the virus, people are confined to their homes, workplaces are closed or only partly operative, and economic activity has slowed substantially. In the consequent economic crisis, competition for jobs between natives and immigrants is likely to accelerate, exacerbating resentment of the latter, especially if they are illegal. Further, normal economic activity may take much time to resume, thrusting many people into hardship. Typically, illegal migrants have scanty savings and, due to fear of discovery, may have no bank account, struggle to obtain loans in any case, and do not qualify for unemployment compensation. The resulting economic distress may engender poverty, which may cascade into social and mental encounters.

\section{Border Crossing}


Most immigrants arrive in their new country with deficient or paltry command of the local language (Portes and Rumbaut, 2014). As time elapses, they improve their linguistic skills. The pace at which they do this is determined by additional exposure factors such as spouse's origin, having children at home, and the ethnic character of their residential neighbourhood; efficiency variables of learning a new language, e.g., level of education and young age at immigration; and economic incentives (Chiswick, Rebhun and Beider, 2020; Kulkarni and Hu, 2014; Van Tubergen and Kalmijn, 2005). People often learn to understand and speak the language first and acquire literacy skills later (Rebhun, 2019). Due to their language handicap, immigrants, especially those with short duration in the country, may not always understand instructions from the government about the safety measures that they must take. Accordingly, they may fail to fully practice social distancing, shelter-in-place, and hygiene, and may not be alert to the tell-tale symptoms of COVID-19. When contagion occurs, communication with medical staff may be disrupted and incomplete, obviating or impairing quick and appropriate treatment. The extent of this effect varies among family members commensurate with their proficiency in the new language. Children tend to acquire proficiency more quickly than do their parents and therefore can serve as translators (Carliner, 2000); men, who tend to join the labour force shortly after settlement, acquire it earlier than women do (Messey et al. 1993). However, when an immigrant is hospitalized the requirements of social distancing make it difficult to use a relative or friend as a reader or interpreter.

\section{Ethnic Segregation}

Immigrants on arrival tend to settle in ethnic enclaves (Alba and Foner, 2017). As their economic attainments improve and they internalize mainstream values, the extent of their segregation is expected to diminish (Zhou and Long, 1991). The least affluent, however, may stay apart for much time (Portes and Jensen, 1987). Immigrant enclaves are located in city centres, in small and densely populated areas of several blocks only (Alba, 1990), causing many inhabitants to suffer from ghettoization (Zoho, 2013) and exhibit a "sticky" spatial configuration (Portes and Rumbaut, 2014). These places are often characterized by social and economic poverty that may aggravate their inhabitants' health vulnerability. The scholarly literature does not always express a consensus regarding the relationship of ethnic residential clusters and health as expressed in metrics such as blood pressure, cholesterol level, dietary behaviours, and physical activity (Osypuk et al., 2009). Likewise, ethnic enclaves vary by origin country (Walton and Takeuchi, 2010). Nevertheless, under residential conditions of multistory and multi-apartment buildings, small apartments, public spaces that serve hundreds of children (staircases, elevators, play areas), and lack of private cars (resulting in intensive use of public transportation), it is more difficult to maintain physical and social distance and rigid principles of hygiene. This places the inhabitants of such enclaves at higher risk of contagion than that of wealthy peers who inhabit nearby luxury towers or choose a suburban lifestyle. Immigrant communities do, however, have advantages that deserve emphasis: they can provide practical resources such as information in the native language, economic assistance, cultural goods, and moral support (Portes and Rumbaut 2014; Xie and Goyette, 2005) that become more important at times of catastrophe and may positively affect health. 


\section{Religiosity}

Migration is a meaningful and sometimes traumatic experience. Religious faith and participation provide cultural continuity and bridges between the old world and the new by offering metaphysical guidance in the spatial journey and enhancing immigrants' consciousness of their religious roots (Kagan, Fong and Reitz, 2020; Lyak-Bowen, 2019; Rebhun, 2014; Vilaca et al., 2014). An immigrant's religious community replaces her or his extended family as a source of social comfort, a framework for ethnic celebration, and a place to seek assistance in realizing economic opportunities (Cadge and Ecklund, 2007). Immigrants turn to religion for supernatural protection against external attacks and discrimination (Portes and Rumbaut, 2014). Alternatively, immigration forces new arrivals to make significant, timeconsuming, and strenuous social and economic adjustments and these, together with the social and cultural stress of living in an unfamiliar environment, make religious participation difficult (Killian, 2001). At times of a frightening pandemic, an existential threat, and uncertainty, immigrants' search for religious grace is likely to increase. Precisely then, however, places of worship are shut down, public worship is banned, and face-to-face encounters with religious leaders become limited if not impossible. The resulting attenuation of the ability of religion to assist immigrants mentally and morally weakens immigrants' resilience to cope with any medical challenge.

\section{Economic Wellbeing}

Immigrants are not made of one cloth; they vary significantly in education and economic attainment by country of origin. However, immigrants generally, and recently landed ones particularly, have lower income than do native-born counterparts with similar educational and professional qualifications (Card and Raphael, 2013). Likewise, a larger proportion of immigrants than of natives is self-employed (Bonacich and Modell, 1980; Borjas, 1986) and hence more economically vulnerable. As these words are written, shops, restaurants, and cafés are closed and people prefer not to order prepared food and avoid professional services in order to cut expenses and minimize the risk of contagion. Unlike employees, the selfemployed do not have a workplace that can safeguard their jobs. Banks may hesitate to lend to them. This is not to say that natives are inured to economic hardship; rather, immigrants, on average, are likely to be more significantly harmed due to their initial economic characteristics. Further, immigrants' economic concerns transcend those at their personal level only; they also impair their ability to send money to family members who stayed behind and to use other instruments of remittance (Carling, 2014). Overall, then, the coronavirus places immigrants at a dual disadvantage: its direct effect on their own economic wellbeing "looming job loss, income loss, workload decline" (Witteveen and Velthorst, 2020: 27222) and its indirect impact on their families abroad ("transnationality")—possibly heightening their psychological stress as well (Teodorowski, Woods and Kennedy, 2020).

\section{Conclusions and Policy Implications}

Immigrants at destination generally, and subgroups defined by the foregoing affinities particularly, are exceptionally vulnerable to the coronavirus. However, immigrants do not operate in a vacuum and the highly contagious nature of this virus suggests that if many immigrants are infected, the local population around them will be at risk as well. Accordingly, it should be in the interest of all inhabitants of immigrant-receiving countries to assure their

\section{Border Crossing}


newcomers the best conditions-in addition to the value of solidarity and mutual responsibility for the weak and needy in times of unrest.

In practical terms, governments should equalize the rights of immigrants with those of the population at large. Both legal and illegal immigrants should receive similar medical care whereas the lifting of their veil of secrecy should not risk their stay in the country. Governments should express sensitivity to immigrants' cultural diversity and publish all coronavirus guidelines in several languages. Special efforts should be made to explain preventive measures to immigrants in ethnic enclaves and guide them in their use. Given the high density of such communities, those in them who fall ill should be immediately evacuated to designated areas where appropriate medical care exists. Religious communities and leaders should find ways to provide immigrant believers with virtual services. If governments offer their citizens financial aid, it should be extended to noncitizen immigrants, certainly those who are legal, thus ensuring that they will not loiter in the street in search of work, exposing themselves to the disease.

Finally, the havoc caused by the pandemic has only just begun. It may be too early to predict whether and how patterns of international migration will change in its wake. Countries may tighten their control over newcomers. People who intend to migrate internationally may reconsider. Those who already immigrated, in turn, may wish to re-migrate if they consider the healthcare system at origin significantly better than that in their new country, believe they can get along better financially by "going home," or wish again to be close to their elderly parents and extended family. In any case, countries should now rethink their immigrantintegration philosophies and policies in order to diminish immigrants' vulnerability to the current disease. Further, the series of infectious viruses that the world has seen in the past two decades-SARS, MERS, and now COVID-19-suggests that global preparations are needed in order to tackle additional pandemics that are widely foreseeable.

\section{References}

Alba, Richard. 1990. Ethnic Identity: The Transformation of White America. New Haven and London: Yale University Press.

Alba, Richard and Nancy Foner. 2017. Strangers No More: Immigration and the Challenges of Integration in North America and Western Europe. Princeton, NJ: Princeton University Press.

Allard John K. 2019. Illegal Immigration in Canada. Immigration News https://www.immigroup.com/ news/illegal-immigration-canada

Blinder, Scott and William L. Allen. 2016. "Constructing Immigrants: Portrayals of Migrant Groups in British National Newspapers, 2010-2012”. International Migration Review 50(1):3-40.

Bonacich, Edna and John Modell. 1980. The Economic Basis of Ethnic Solidarity: Small Business in the Japanese American Community. Berkeley: University of California Press.

Borjas, George J. 1986. "The Self-Employment Experience of Immigrants”. Journal of Human Resources 21(4): 485-506.

Cadge, Wendy and Elaine H. Ecklund. 2007. "Immigration and Religion". Annual Review of Sociology 33: 359-379.

Card, David and Steven Raphael. 2013. Immigration, Poverty and Socioeconomic Inequality. New York: Russell Sage Foundation.

Carliner, G. 2000. "The Language Ability of U.S. Immigrants: Assimilation and Cohort Effects". International Migration Review 34: 158-182. 
Carling, Jørgen. 2014. "Scripting Remittances: making Sense of Money transfers in Transnational Relationships". International Migration Review 48(S1): 218-262.

Chiswick, Barry R., Uzi Rebhun and Nadia Beider. 2020. "Language Acquisition, Employment Status, and the Earnings of Jewish and Non-Jewish Immigrants in Israel". International Migration 58(2): 205232.

Connor, Phillip, Jeffrey S. Passel and Jens Manuel Krogstad. 2019. How European and U.S. Unauthorized Immigrant Population Compare. Washington D.C.: Pew Research Center. https://www.pewresearch. org/fact-tank/2019/11/13/how-european-and-u-s-unauthorized-immigrant-populationscompare/

Connor, Phillip and Jeffrey S. Passel. 2019. Four Countries Account for the Majority of Europe's Unauthorized Immigrant Population. Washington D.C.: Pew Research Center. https://www.pewresearch.org/ global/2019/11/13/four-countries-account-for-the-majority-of-europes-unauthorizedimmigrant-population/

De Genova, Nicholas P. 2002. "Migrant Illegality and Deportability in Every Day Life". Annual Review of Anthropology 31: 419-447.

Garcia, Angela. 2019. Legal Passing: Navigating Undocumented Life and Local Immigration Law. Oakland: University of California Press.

Jin, Jin, Neha Agarwala, Prosenjit Kundu, Benjamin, Harvey, Yuqi Zhang, Eliza Wallace and Nilanjan Chatterjee. 2021. "Individual and Community-Level Risk for COVID-19 Mortality in the United States". Nature Medicine 27, 264-269. https://doi.org/10.1038/s41591-020-01191-8

Kagan, Irena, Eric Fong and Jeffrey G. Reitz. 2020. "Religion and Integration among Immigrants and Minority Youth". Journal of Ethnic and Migration Studies 46(17): 3543-3558.

Keni Raghuvir, Anila Alexander, Pawan Ganesh Nayak, Jayesh Mudgal and Krishnadas Nandakumar. 2020. "COVID-19: Emergence, Spread, Possible Treatments, and Global Burden". Front. Public Health 8:216. doi: 10.3389/fpubh.2020.00216.

Killian, Caitlin E. 2001. Cultural Choices and Identity Negotiation of Muslim Maghrebin Women in France. Atlanta, GA: Unpublished Ph.D. Dissertation, Emory University.

Kulkarni, Veena S. and Xiaohan Hu. 2014. "English Language Proficiency among the Foreign Born in the United States, 1980-2007: Duration, Age, Cohort Effects”. International Migration Review 48(3): $762-800$.

Lyak-Bowen, Majbritt. 2019. “A Multireligious Approach to the Integration of Migrants in Europe: An Examination of Migrants' Views on and Experiences of Taking Part in Multireligious Integration Projects". Border Crossing 9(2): 79-96.

Massey, Douglas S., Joaquin, Arango, Graeme Hugo, Ali Kouaouci, Adela Pellegrino, and J. Edward Taylor. 1993. "Theories of International Migration: A Review and Appraisal". Population and Development Review 19(3): 431-466.

Massey, Douglas S. and Katherine Bartley. 2005. "The Changing Legal Status Distribution of Immigrants: A Caution”. International Migration Review 39(2): 469-484.

Massey, Douglas S. and Chiara Capoferro. 2007. "Measuring Undocumented Migration". In: Alejandro Portes and Josh DeWind (eds.) Rethinking Migration: New Theoretical and Empirical Perspectives. New York and Oxford: Berghahn Books, pp. 257-284.

McLuhan, Marshall and Bruce R. Powers. 1992. The Global Village: Transformations in World Life and Media in the $21^{\text {st }}$ Century. New York: Oxford University Press.

Osypuk, Theresa L., Ana V. Diez Roux, Craig Hadley and Namratha R. Kandula. 2009. “Are Immigrant Enclaves Healthy Places to Live? The Multi-Ethnic Study of Atherosclerosis". Social Science and Medicine 69(1): 110-120.

Portes, Alejandro and Leif Jensen. 1987. "What's an Ethnic Enclave? The Case for Conceptual Clarity". American Sociological Review 52: 768-771.

Portes, Alejandro and Ruben G. Rumbaut. 2014. Immigrant America: A Portrait. Oakland: University of California Press (Fourth Edition). 
Raijman, Rebeca and Marta Tienda. 1999. “Immigrants' Socioeconomic Progress Post-1965: Forging Mobility or Survival?” In: Charles Hirscman, Philip Kasinitz and Josh DeWind (eds.), The Handbook of International Migration: The American Experience. New York: Russell Sage Foundation, pp. 239-256.

Rebhun, Uzi. 2014. "Immigrant Acculturation and Transnationalism: Israelis in the United States and Europe Compared". Journal for the Scientific Study of Religion 53(3): 613-635.

. 2019. Language Acquisition, Citizenship, and Employment among Israeli Immigrants in Germany. Paper presented at Friedrich-Schiller University, Jena, Germany (31.1.2019).

Sciortino, Giuseppe. 2012. "The Regulation of Undocumented Migration". In: Marco Martiniello and Jan Rath (eds.), An Introduction to International Migration Studies: European Perspectives. Amsterdam: Amsterdam University Press, pp. 351-378.

Szea, Shirley, Daniel Pan, Clareece R. Nevill, Laura J. Gray, Christopher A. Martin, Joshua Nazareth, Jatinder S. Minhas, Pip Divall, Kamlesh Khunti, Keith R. Abrams, Laura B. Nellums, and Manish Pareek. 2020 (forthcoming). "Ethnicity and Clinical Outcomes in COVID-19: A Systematic Review and Meta-Analysis". EClinicalMedicine (Published by The Lancet), 29-30.

Teodorowski, Piotrs, Ruth Woods and Catriona Kennedy. 2020. "The Mental Health and Wellbeing of EU Citizens in the UK: A Systematic Review of the Qualitative Literature”. Border Crossing 10(1): 43-60.

Van der Leun, Joanne and Maria Ilies. 2012. "Undocumented Migration: An Explanatory Framework". In: Marco Martiniello and Jan Rath (eds.), An Introduction to International Migration Studies: European Perspectives. Amsterdam: Amsterdam University Press, pp. 305-326.

Van Tubergen, Frank and Matthijs Kalmijn. 2005. "Destination-Language Proficiency in CrossNational Perspective: A Study of Immigrant Groups in Nine Western Countries". American Journal of Sociology 110(5):1412-1457.

Vilaca, Helena, Enzo Pace, Inger Furseth and Per Pettersson (eds.) 2014. The Changing Soul of Europe: Religions and Migrations in Northern and Southern Europe. Farnham, UK: Ashgate Publishing.

Walton, Emily and David Takeuchi. 2010. Ethnic Residential Clustering and Health in West Coast States. DIALOGUE in Research and Policy, No. 2. Seattle: University of Washington: West Coast Poverty Center.

Witteveen, Dirk and Eva Velthorst. 2020. "Economic Hardship and Mental Health Complaints during Covid-19". Proceedings of the National Academy of Sciences of the United States of America 117(44): 2727727284.

Xie, Yu and Kimberly A. Goyette. 2005. “A Demographic Portrait of Asian Americans”. In: Reynolds Farley and John Haaga (eds.), The American People: Census 2000. New York: Russell Sage Foundation, pp. 415-446.

Zhou, Min. 2013. "Ethnic Enclaves and Niches". In: Immanuel Ness (ed.) The Encyclopaedia of Global Human Migration. Oxford: Wiley Blackwell, Vol. III, pp. 1333-1337.

Zhou, Min and John R. Logan. 1991. "In and Out of China Town: Residential Mobility and Segregation of New York City's Chinese". Social Forces 70(2): 387-407. 